\title{
Fostering students' autonomy in learning English in nonlinguistic university
}

\author{
Oksana Pershukova ${ }^{1, *}$, Nina Nikolska ${ }^{2}$, and Oksana Vasiukovych $^{1}$ \\ ${ }^{1}$ National Aviation University, 1 Lubomyra Guzara Ave., Kyiv, Ukraine \\ ${ }^{2}$ National University of life and environmental sciences of Ukraine, 15 Heroiv Oborony Str., Kyiv, Ukraine
}

\begin{abstract}
The study aims to find out whether it is possible to foster students' learner autonomy in the context of ESP language learning in non-linguistic universities by using a special approach. The experiment was carried out at National Aviation University in Ukraine with two groups of first-year students of electronics (experimental and control) in 2018-2019. Testings to determine students' level of communicative competence in English and surveys to identify students' level of learner autonomy development were conducted in September and May of the same year of education. The control group did not receive any special training, while in the experimental group were created special learning conditions. With the purpose to prepare students to accept responsibility for their learning, they were given the opportunities to choose educational materials; to set goals of their learning; to reflect the process and evaluate the results of learning, etc. Modern technologies were widely used as well as scaffolding (if necessary). According to the results of the experiment, it was stated that only a part of the most active students used the created conditions and gained experience in autonomous learning. The conclusion was made about creating such an environment. It is a challenge that is appropriate to realize to give an autonomous learning experience to aspiring students.
\end{abstract}

\section{Introduction}

\subsection{The problem statement}

Education in the age of globalization and integration is closely linked to the level of competitiveness of university graduates, which today largely depends on their ability to work with information, self-study and acquire knowledge independently. At the same time, the new Ukrainian educational standards introduction has resulted in the transfer of a large part of the work aimed at the mastering of educational material to outside the classroom, leaving the volume and content of the programs unchanged. The discrepancy between the amount of knowledge a student has to absorb and the time allotted for this makes him or she look for effective ways to organize students' independent work. The problem of students' willingness to learn for a lifetime depends on the development of self-directed learning activities. In this regard, students' independent learning activity has a special role and involves the transition to a 'subject-subject' interaction between a teacher and a student, shifting a focus on active methods of mastering knowledge. Therefore, the whole learning process should be re-oriented towards promoting students' selfdevelopment, motivation raising, and learners' autonomy fostering.

In the current conditions of globalization and integration, the willingness to communicate freely with representatives of different peoples and cultures is a demand of time, which is why the whole world is now engrossed in mastering foreign languages. Modern professional education in Ukraine in this context aims at training a specialist ready to work in the flow of foreignlanguage scientific information and communication with foreign colleagues able to work with professional scientific literature and to learn new technologies because the level of competitiveness of a modern specialist depends largely on using a foreign language. English is considered now as a lingua franca, a means of international and intercultural communication. At the same time, the modern realities in Ukraine are that: a) students of non-linguistic universities have a rather heterogeneous level of competence in English (because sometimes they studied German or French as a foreign language at school); b) students are not always interested in a foreign language, because they poorly conceive the importance of this discipline in his/her future professional activity; c) the amount of time allocated for classwork at the university is constantly decreasing, extending the amount of students' independent work.

In these conditions, there is a contradiction between the objective necessity of a high level of foreign language competence of a modern specialist and the real state of affairs in non-linguistic universities in Ukraine, since the level of such training does not meet the requirements of the present and needs improvement. This problem can be considered in many aspects, and in our opinion, the aspect of creating conditions for

\footnotetext{
* Corresponding author: pershoks@gmail.com
} 
students' autonomous learning in the current circumstances is one of the requiring solutions. Ways of fostering the development of students' autonomous learning English should be considered as one of the urgent tasks of the learning process at a non-linguistic university. Learners' autonomy has a high priority in the new education system since its formation through the mechanical transfer of knowledge from teacher to student is not possible, it can be developed. Knowing how students' autonomy can be fostered, how to make every student an autonomous learner and successful user of English would help us to make our educational system more efficient.

\subsection{Literature review}

Students' autonomy in the foreign language learning process. As far as researches for a long time failed to reach a consensus on what the notion of students' autonomy exactly is until recently some scientists have characterized students' autonomy as a controversial and problematic term. Little indicates that: 'it is often confused with 'self-instruction' [1]. Karastateva states that 'it is loosely used along with 'autonomous learning' [2]. Benson points out the number of related but not fully synonymic to autonomy terms (self-access, self-study, self-education, out of class learning, distance learning), and explained the difference in such way: 'they describe the way and degrees of learning by yourself, whereas autonomy refers to abilities and attitudes... as well as the capacity to control own learning'. The researcher also mentions that among other terms used as synonyms in discussions on the issues of students' autonomy is self-directed learning or independent learning. That's why he stresses the necessity to check what the author exactly meant by using them [3].

Learner autonomy has become a topic of interest and discussions over the last two decades. As Benson indicated, it was caused by some learner-centred approaches to language education, which included different aspects of independence of learning. The early history of the notion of autonomy in language education begins with Holec's seminal report to the Council of Europe's Modern Languages Project [4]. According to still influential Holec's [5, p.3] definition of learner autonomy in it is 'the activity that a learner has developed to take charge of his or her learning'. The researcher underlines that this activity includes: a) determining the learning objectives; b) defining its contents; c) selecting methods and techniques; d) monitoring the procedure, as well as evaluating the results. He stressed that self-assessment is an important and integral element of learner autonomy. This point of view is supported by many pieces of research, among them is Little [6, p.175], who asserted that 'the basis of learner autonomy is that the learner accepts responsibility for his/her learning'. According to Benson, the wide notion of autonomy can be classified as technical autonomy: the act of learning language outside the framework of an educational institution and without the intervention of a teacher; psychological autonomy: a capacity which allows learners to take more responsibility for their learning; political autonomy: control over the processes and content of learning [cited in Finch, 7]. Benson \& Voller made a significant contribution to the field by clarifying the difference between autonomy and independence in language learning.

They stated five ways the term autonomy can be used:

1) for situations in which learners study entirely on their own;

2) for a set of skills which can be learned and applied in self-directed learning;

3) for an inborn capacity which is suppressed by institutional education;

4) for the exercise of learners' responsibility for their learning;

5 ) for the right of learners to determine the direction of their learning [8, p. 2].

Ommagio determined some features of the ideal autonomous learners. They are considered to have insights into their language styles and strategies, to take an active approach to the learning task, to be willing to take risks, to be good guessers, to attend to form as well as content and to have a tolerant as well as the outgoing approach to the target language... [cited in Thanasoulas, 2000, 9]. According to Littlewood, responsibility and ability are the two main dimensions of learner autonomy. Students must take responsibility for their learning, because, they are the ones who do the learning. Besides that, the students are responsible for some process which traditionally belonged to their teacher. These processes include deciding on learning objectives, selecting learning methods, evaluating the results of learning. Ability means the students' capability to complete the processes or tasks connected to responsibility [10]. Some later researches supported these ideas, as Bajramy who indicated that 'learners should be able to build their criteria for the quality of their work...be independent... and be able to make judgments for their strong and weak points of learning' [11, p.425]. So, to become an autonomous learner it is expected that one will be able to 'set personal learning goals, to identify learning strategies and develop study plans to achieve these goals, select relevant resources and support, assess and reflect on one's progress' [12].

Holec pointed out that autonomy is an attribute of the learner. He stressed that 'it's not inborn ability so it must be acquired by the learner either by natural means or by formal learning, i.e. in a systematic, deliberate way" [5, p. 3]. Dickinson indicated that 'learners do not automatically accept responsibility' for their learning and 'do not necessarily find it easy to reflect on the learning process. Teachers must... provide them with appropriate tools and opportunities'. Dickinson also stressed that the liberalization of the classroom will help the students to take responsibility for their learning. Thus, the learner has the responsibility to make decisions and take charge of his/her learning [13]. Little supported this idea considerably with words 'learners who take responsibility for their learning are more likely to achieve their learning targets'. But without suitable guidance, the student will not be able to become aware 
of the possibilities [6, p. 176]. So, the teachers' role is very important in students' autonomous learning and cannot be ignored. The relationship between teachers' autonomy and learners' autonomy has been in the centre of many researchers' attention. Among them is Little, who called attention to the importance of having autonomous teachers to promote students' autonomy as well as highlighting the necessity to analyze and research this concept thoroughly. He indicated the idea that 'learner autonomy develops through pedagogical dialogues in which teachers exercise their own autonomy' [6]. Littlewood reviewed teachers' autonomy from two different perspectives: as the capacity for independent decision making, which involves having abilities and skills for action: and as willingness, which includes motivation and confidence to make a choice [14]. Benson named the concept of teacher' autonomy as 'one of the most significant and problematic' because 'in the language teaching literature, there is a much greater emphasis on teacher autonomy as a professional attribute and the link between teacher autonomy and learner autonomy' [4]. Thus, to be able to foster students' autonomy in the classroom the teacher has to be autonomous him/herself.

There is a strong need for support and supervision of language learners' as they are moving toward their autonomy developing. The process to make the students become masters of their autonomous learning is not easy, because the teacher and the students 'must shift their roles so it can be created a positive learning atmosphere' [11]. Dickinson described autonomy as 'the learning situation in which the learner is responsible for all the decisions made and implemented concerning his learning and the teacher becomes a skilled manager of human beings' [13, p. 11]. To reach this goal the researcher pointed out to the teachers six ways for promotion learners' independence in his paper [15, p. 2]. They are:

1) legitimizing independence in learning by showing that teachers are approving and encouraging the students to be more independent;

2) giving learners successful experiences of independent learning and convincing them that they are capable of greater independence;

3) giving learners opportunities to exercise their independence;

4) helping learners to develop learning techniques (learning strategies) so they can exercise their independence;

5) helping learners to become more aware of language as a system so that they can understand many of the learning techniques available and learn sufficient grammar to understand simple reference books;

6) sharing with learners something of what we know about language learning so they have a greater awareness of what to expect from the language learning task and how they should react to problems that erect barriers to learning [15].

Thus, learners do not automatically accept responsibility for their learning in formal contexts and do not find it easy to reflect on the learning process. Teachers must provide them with appropriate tools and opportunities to practice using them $[6, \mathrm{p} .176]$. The significance and importance of learner autonomy functioning at the university level pointed out Bajrami 'Learner autonomy ...undertakes the outcomes at the university level such as flexibility, adaptation, selfinitiative and self-direction'... promotes democratic education societies, prepares individuals for a lifelong learning process,... makes the best opportunity for learners to use their creative ideas in and out of the classroom' [11].

So, according to scholars' papers mentioned above, we can conclude that students' autonomy is a complex notion. It means the activity that a learner has to develop for the most successive learning and it anticipates that every student has to take charge of his/her learning, which includes: determining the learning objectives, defining its contents and selecting methods and techniques, monitoring the procedure, as well as evaluating the results. Students' autonomy has three dimensions: responsibility, ability and capability. The basis of learner autonomy is that the learner's acceptance of responsibility for his/her learning, while the ability is the language learning aptitude, as well as his/her capability means readiness to complete the processes or tasks connected to responsibility. Student's autonomy is an attribute of the learner, it's not inborn ability Teachers have to provide students with appropriate tools and opportunities to develop it through the liberalization of the classroom and creation a positive learning environment as well as pedagogical dialogues in which teachers exercise their own autonomy.

The concept of teachers' autonomy in our interpretation means teachers' willingness and capacity to take control of teaching and learning to make the learners active and independent in their learning.

We understand learners' autonomy in ESP language learning as educational work performed by students under the methodological and scientific guidance of the teacher in the context of gaining knowledge and skills to accept responsibility for their learning in meeting the specific needs of the future professional English communication requirements and in this meaning we use it in the paper.

\section{The study}

Based on the above considerations, the current study attempted:

- to explore the concept of students' autonomy in the ESP language learning process;

- to create a learning environment that is favourable for students' autonomy fostering;

- to examine how much students' activity in autonomous work associates with their progress.

The following research questions were posed:

- How is it possible to create a favourable learning environment for students' autonomous learning in the context of ESP?

- Whether factors of learning environment for students' autonomy developing make a real difference in students' educational success?

It was anticipated that forming students' autonomy in learning will make a positive influence on their 
motivational intensity, they will be more satisfied with learning English and their results in education will be better. The study is based on the analysis of scientific papers and materials on the topic of research and exploring the effectiveness of the created learning environment, in which the students of the experimental group used special strategies for autonomous learning, while the students of the control group studied in traditional conditions.

\subsection{Participants}

The participants of our study were 38 first-year students of the National Aviation University specialty: 151 'Automation and Computer-Integrated Technologies'. Out of 38 participants, 9 were females and 26 males who ranged from 17 to 20 years. At the time of research, English for Specific Purposes (ESP) lessons were part of their official university curriculum. Although the students were registered in two different groups (control and experimental, matched by English language proficiency level) the research was conducted by the same teacher who followed the same procedure and used the same materials for questioning and forming the ability to independent learning activity in both groups. According to the curriculum, two-hour classes were held once a week for two semesters. Testing was conducted in the control and experimental groups at the beginning and the end of the academic year.

Students' language competence was assessed in the control and experimental groups by the course teacher and her two colleagues at the beginning and the end of the academic year and grades were considered as an indication of their achievement. To determine students' characteristics in terms of autonomy they were suggested to answer (anonymously) the questionnaire to investigate their views on their responsibilities in learning and decision-making abilities. As some other researchers [16] we used Joshi's (2011) Learner Autonomy Questionnaire in our work, which was conducted in English and was supplemented by a translation into Ukrainian (students' native language). To answer the questionnaire there was suggested the Likert scale with 5 ready answers (strongly agree - agree - neutral disagree - strongly disagree). We suggested students of both (experimental and control) groups answer the questions twice at the end of September (at the beginning of the year of education) and in May (at the end of the same year of education).

It is worth noting that students' level of communicative competence in both groups was miscellaneous. As it was found that 7 students of the experimental group and 5 students from the control group had a Pre-intermediate level of language competence, which is not enough to master the course of ESP (Electronics) and absence skills of independent work. They were suggested special consultations on grammar and language practice improvements. For such students of both groups, the amount and content of their independent work were defined. Besides, all the students were taught how to navigate background materials and use different sources of information. At the language practice classes, students of the control group were taught using traditional teaching methods. In the experimental group, we used a special learning approach which is based on a special environment creation and using strategies for students' autonomy fostering. The purpose of the approach was to prepare students to accept responsibility for their learning:

- the analysis of the situation and determination of the goal;

- development of the plan of the desired achievement;

- determination of available means and resources;

- implementation of the plan and development of the corrective actions plan (if necessary);

- real-life incorporation into the process of students learning.

To prepare students for the gradual transfer them functions of the organizer, during the learning process they were suggested:

- to discuss problems about the future profession (individually or in groups) in the form of short talks (to make them feel the importance of learning English for the future profession);

- to pick the topics (for projects, guidelines, and rubrics), and present the results of work in the class (to make them feel responsible for what happens during the lesson);

- to keep personal blogs or written journals reflecting their learning experiences (positive and negative);

- to obtain self-evaluation constantly (students are given the possibility to be in charge of their learning);

- to create resources for learning, that relate to the content of the lesson (make them feel involved in the process of learning).

\subsection{Methods}

During the course preparation, we used the ideas expressed by the scientists whose works we analysed in the chapter Literature review in our interpretation. Active teaching methods were used - including simple tasks, which are based on a students' creativity, such as projects, presentations, topics related to current problems of the future students' speciality. Students were asked to keep personal blogs or written journals to help them to identify their strengths and weaknesses, to make it possible to find ways to improve the learning results, to inform the teacher about likes and dislikes in the learning process. Such tasks were of particular interest to students, they contributed to the development of their critical thinking, analysis, and synthesis of information. At the end of the year, preference was given to assignments that motivate students to self-improvement, learning activities with a taste of competitiveness, including participation in competitions, discussions, and debates. In such circumstances, the teacher acted as a consultant, and the level of students' independence in the tasks was increasing, as was the quality of the educational activity. We consider that several types of tasks can be used at different stages for the development of students' independent work, namely: educational (at the very beginning the teacher instructs the way of doing, later the students use scaffolding if necessary); training (model implementation is provided); searching (to be performed independently by each student). They 
are united by a common requirement - the clarity and controllability of results and accounting in the appraisal. Educational and training tasks are certainly necessary, especially at the initial stage as preparatory to demonstrating possible actions within the complex independent educational activity; search tasks are relevant at an advanced stage.

It is expected that an autonomous learner is able:

a) to set personal learning goals;

b) to identify learning strategies and develop study plans to achieve these goals;

c) to select relevant resources and support;

d) to assess and reflect on one's progress;

e) to accept responsibility for learning.

That is why we have set the task of identifying changes in the level of student autonomy during the academic year (at the beginning and at the end of the experiment). For this we need:

1. To diagnose students' awareness in language learning which includes students' perceiving of own abilities, possibilities and capabilities.

2. To find out students' level of willingness to development and their ability to set personal learning goals.

3. To discover students' readiness to accept responsibility for learning, assess and reflect on progress.

4. To identify students' learning strategies and their readiness to develop study plans and achieve stated objectives.

5. To come to know about students' ability to select relevant resources and support.

6. To distinguish students' attitude to the role of the teacher.

\subsection{Results}

The results of the study are presented in this section. The data, which were mainly elicited from the survey questions, are reported in Tables 1-9. According to Joshi's questionnaire numbers of questions are used for demonstrating subheadings:

Items 1-3 - Learner awareness in language learning.

Items 4-8 - Students' self-effort in learning English.

Items 9-13 - Learners' broader autonomous activities beyond the class.

Item 14 - Learners self-esteem.

Items 15-16 - Learners' use of references materials.

Item 17 - Learners self-motivation in learning.

Item 18 - Learners' use of computers and the internet for English learning.

Items 19-23 - The role of a learner;

Items 24-29 - Learners' of perceptions of teachers' role.

In commenting them we can affirm:

Table 1, items 1-3. The data of the experimental group in September indicates that only $40 \%$ of respondents believe they can learn, $35 \%$ know how to study languages well in free time and only $15 \%$ were able to make their own decisions and set goals. The data received in May demonstrates the changes in the situation: $70 \%$ believe they can learn, $65 \%$ can make their own decisions and set goals, and $75 \%$ know how to study languages well in free time. The data of the control group in September and May has some differences, but they are not so significant $(44,4 \% \rightarrow 38,9 \% ; 27,8 \% \rightarrow$ $33,3 \% ; 22,3 \% \rightarrow 33,3 \%$ ) as in the experimental group.

Table 1. Learner awareness in language learning.

\begin{tabular}{|c|c|c|c|c|c|}
\hline \multirow{2}{*}{ No } & \multirow{2}{*}{ Items } & \multicolumn{2}{|c|}{$\begin{array}{c}\text { experimental } \\
\text { group (\%) }\end{array}$} & \multicolumn{2}{|c|}{$\begin{array}{c}\text { control group } \\
\text { (\%) }\end{array}$} \\
\cline { 3 - 6 } & Sept & May & Sep & May \\
\hline 1. & $\begin{array}{c}\text { I think I can learn English } \\
\text { well. }\end{array}$ & 40 & 70 & 44,4 & 38,9 \\
\hline 2. & $\begin{array}{c}\text { I make decisions and set } \\
\text { goals for my learning. }\end{array}$ & 15 & 65 & 27,8 & 33,3 \\
\hline 3. & $\begin{array}{c}\text { I make good use of my free } \\
\text { time studying English. }\end{array}$ & 35 & 75 & 22,2 & 33,3 \\
\hline
\end{tabular}

Legend: No - Item Serial Number, \% - Responses in percentage

Table 2. Students' self-effort in learning English.

\begin{tabular}{|c|c|c|c|c|c|}
\hline \multirow{2}{*}{ No } & Items & \multicolumn{2}{|c|}{$\begin{array}{c}\text { experimental } \\
\text { group (\%) }\end{array}$} & \multicolumn{2}{c|}{$\begin{array}{c}\text { control } \\
\text { group (\%) }\end{array}$} \\
\cline { 3 - 6 } & Sept & May & Sep & May \\
\hline 4. & I preview before the class. & 0 & 35 & 5,6 & 16,7 \\
\hline 5. & $\begin{array}{c}\text { I try to use every opportunity } \\
\text { to take part in activities where I } \\
\text { can speak in English. }\end{array}$ & 25 & 70 & 22,2 & 22,2 \\
\hline 6. & $\begin{array}{c}\text { I speak confidently in front of } \\
\text { the people. }\end{array}$ & 10 & 60 & 5,6 & 27,8 \\
\hline 7. & $\begin{array}{c}\text { I make notes and summaries of } \\
\text { my lessons. }\end{array}$ & 5 & 30 & 5,6 & 16,7 \\
\hline 8. & $\begin{array}{c}\text { I talk to the teachers and } \\
\text { friends outside the class in } \\
\text { English. }\end{array}$ & 0 & 35 & 0 & 11,1 \\
\hline
\end{tabular}

Table 2, items 4-8. The data of experimental group demonstrated that at the beginning of the experiment nobody $(0 \%)$ systematically previewed their tasks before the class and only $25 \%$ tried to use all possible opportunities to take part in the English speaking activities, while later data show that $70 \%$ of them made plenty of efforts by using every opportunity of participation in the English speaking activities during the lessons. Item 6 demonstrates that respondents were almost not ready to speak confidently in front of the people or to talk English to the teachers and friends outside the class, and didn't find it necessary to make notes and talk English outside the class. But at the end of the year, they agreed that they became more confident in English speaking, recognized the benefits of making notes and summaries of lessons and some of them became ready for English communicating outside the classroom. The data of the control group shows that 1 student $(5,6 \%)$ previewed in September and his example was followed by one more student. It can be observed that $22,2 \%$ of respondents tried to use every opportunity to take part in English speaking activities and this data remained unchanged. The ability to speak confidently in front of the people demonstrates changes: from 5,6\% in September to $27,8 \%$ in May. Analyzing the data on making notes and summaries we can admit the growth from $5,6 \%$ to $16,7 \%$ of respondents. The ability to communicate out of class grew from $0 \%$ to $11,1 \%$. 
Table 3. Learners' broader autonomous activities beyond the class.

\begin{tabular}{|c|c|c|c|c|c|}
\hline \multirow[t]{2}{*}{ No } & \multirow[t]{2}{*}{ Items } & \multicolumn{2}{|c|}{\begin{tabular}{|c} 
experimental \\
group $(\%)$
\end{tabular}} & \multicolumn{2}{|c|}{$\begin{array}{c}\text { control } \\
\text { group }(\%)\end{array}$} \\
\hline & & Sept & May & Sept & May \\
\hline 9. & $\begin{array}{l}\text { I practice English outside the } \\
\text { class also such as record my } \\
\text { voice; speak to other people in } \\
\text { English. }\end{array}$ & 0 & 45 & 0 & 22,2 \\
\hline 10. & $\begin{array}{l}\text { I use the library to improve my } \\
\text { English. }\end{array}$ & 0 & 0 & 0 & 0 \\
\hline 11. & $\begin{array}{c}\text { I use audio-visual materials to } \\
\text { develop my speech (listen to } \\
\text { the BBC, watch movies, read } \\
\text { newspapers, etc.) }\end{array}$ & 35 & 75 & 33,3 & 61,1 \\
\hline 12. & $\begin{array}{l}\text { I attend seminars, training } \\
\text { courses, conferences to } \\
\text { improve my English. }\end{array}$ & 15 & 55 & 22,2 & 22,2 \\
\hline 13. & $\begin{array}{l}\text { I take a risk in learning the } \\
\text { English language. }\end{array}$ & 0 & 30 & 0 & 27,8 \\
\hline
\end{tabular}

Table 3, items 9-13. The data demonstrated significant growth in practising English in the period from September till May in both groups (experimental: $0 \% \rightarrow 45 \%$ and control: $0 \% \rightarrow 22,2 \%$ ) It was rather strange to reveal that no one student from both groups used a library during the period of research. The results of responses showed that students actively used a wide range of audio-visual materials to develop their language ability (experimental: $35 \% \rightarrow 75 \%$ and control: $33,3 \% \rightarrow 61,1 \%)$. The results of attending training courses, seminars and conferences are rather different. They grew in the experimental group but remained unchanged in control (experimental: $15 \% \rightarrow 55 \%$ and control: $22,2 \% \rightarrow 22,2 \%$ ). It can be seen that students of both groups demonstrated readiness to take some risk in learning English, especially significant growth was in experimental group $0 \% \rightarrow 30 \%$, while Control demonstrated $0 \% \rightarrow 22,2 . \%$, which proves students' autonomy development.

Table 4. Learner's self-esteem.

\begin{tabular}{|c|c|c|c|c|c|}
\hline \multirow{2}{*}{ No } & \multirow{2}{*}{ Item } & \multicolumn{2}{|c|}{$\begin{array}{c}\text { experimental } \\
\text { group (\%) }\end{array}$} & \multicolumn{2}{c|}{$\begin{array}{c}\text { control } \\
\text { group (\%) }\end{array}$} \\
\cline { 3 - 6 } & Sept & May & Sept & May \\
\hline \multirow{2}{*}{14.} & $\begin{array}{c}\text { I note my strengths and } \\
\text { weaknesses in learning } \\
\text { English and improve them. }\end{array}$ & 0 & 85 & 11,1 & 33,3 \\
\hline
\end{tabular}

Table 4, item 14. This item demonstrated striking growth of positive answers in the experimental group $(0 \% \rightarrow 85 \%)$, which means students reflecting their learning experiences, attempts to improve quality of learning, as well as significant changes in students' selfevaluation in the control group $11,1 \% \rightarrow 33,3$.

Table 5, items 15-16. The data of experimental group demonstrated that only half of the total respondents' number revised lessons, and read extra materials in advance at the beginning of the experiment, but this number significantly changed by more in May $(50 \%$ $\rightarrow 90 \%$; and $45 \% \rightarrow 75 \%$ ), which proves students' selfinitiative development. The data of the control group remained almost without changes $(66,7 \% \rightarrow 66,7 \%$ and $50,0 \% \rightarrow 55,6 \%$ ).

Table 5. Learners' use of references materials.

\begin{tabular}{|c|c|c|c|c|c|}
\hline \multirow{2}{*}{ No } & Items & \multicolumn{2}{|c|}{$\begin{array}{c}\text { experimental } \\
\text { group (\%) }\end{array}$} & \multicolumn{2}{c|}{$\begin{array}{c}\text { control } \\
\text { group (\%) }\end{array}$} \\
\cline { 3 - 6 } & Sept & May & Sept & May \\
\hline 15. & $\begin{array}{c}\text { I revise lessons and seek the } \\
\text { reference books }\end{array}$ & 50 & 90 & 66,7 & 66.7 \\
\hline 16. & $\begin{array}{c}\text { Besides the contents } \\
\text { prescribed in the course, I read } \\
\text { extra materials in advance }\end{array}$ & 45 & 75 & 50,0 & 55,6 \\
\hline
\end{tabular}

Table 6. Learners self-motivation in learning.

\begin{tabular}{|c|c|c|c|c|c|}
\hline \multirow{2}{*}{ No } & Items & \multicolumn{2}{|c|}{$\begin{array}{c}\text { experimental } \\
\text { group (\%) }\end{array}$} & \multicolumn{2}{c|}{$\begin{array}{c}\text { control } \\
\text { group (\%) }\end{array}$} \\
\cline { 3 - 6 } & Sept & May & Sept & May \\
\hline 17. & $\begin{array}{c}\text { When I make progress in } \\
\text { learning, I reward myself such } \\
\text { as: buy new things, celebrate } \\
\text { parties, etc. }\end{array}$ & 35 & 85 & 16,7 & 50,0 \\
\hline
\end{tabular}

The data in Table 6, item 17 demonstrated the respondents' attitudes toward self-motivation. Both groups showed the intensive growth $(35 \% \rightarrow 85 \%$ and $16,7 \rightarrow 50,0 \%$ ), which proved that this activity is popular among some students.

Table 7. Learners' use of computers and the internet for English learning.

\begin{tabular}{|c|c|c|c|c|c|}
\hline \multirow{2}{*}{ No } & \multirow{2}{*}{ Items } & \multicolumn{2}{|c|}{$\begin{array}{c}\text { experimental } \\
\text { group (\%) }\end{array}$} & \multicolumn{2}{c|}{$\begin{array}{c}\text { control } \\
\text { group (\%) }\end{array}$} \\
\cline { 3 - 6 } & Sept & May & Sept & May \\
\hline 18. & $\begin{array}{c}\text { I use the internet and } \\
\text { computers to study and } \\
\text { improve English. }\end{array}$ & 60 & 95 & 55,6 & 100,0 \\
\hline
\end{tabular}

The data in Table 7, item 18 indicated that modern technologies are very popular among language learners. The data of the experimental group demonstrated $60 \%$ $\rightarrow 100 \%$, and the control group 55,6 \% 72,2\%. It looks like this item explains the students' refusal to visit the libraries.

Table 8. The role of a learner.

\begin{tabular}{|c|c|c|c|c|c|}
\hline \multirow{2}{*}{ No } & Items & \multicolumn{2}{|c|}{$\begin{array}{c}\text { experimental } \\
\text { group (\%) }\end{array}$} & \multicolumn{2}{c|}{$\begin{array}{c}\text { control } \\
\text { group (\%) }\end{array}$} \\
\cline { 3 - 6 } & Sept & May & Sept & May \\
\hline 19. & $\begin{array}{c}\text { Students have to be responsible } \\
\text { for finding their ways of } \\
\text { practicing English. }\end{array}$ & 30 & 95 & 27,8 & 38,9 \\
\hline 20. & $\begin{array}{c}\text { Students should use many self- } \\
\text { study materials to learn } \\
\text { English. }\end{array}$ & 15 & 55 & 16,7 & 33,3 \\
\hline 21. & $\begin{array}{c}\text { Students have to evaluate } \\
\text { themselves to learn better. }\end{array}$ & 20 & 70 & 11,1 & 11,1 \\
\hline 22. & $\begin{array}{c}\text { Students should mostly study } \\
\text { that has been mentioned under } \\
\text { the course for exam purposes. }\end{array}$ & 60 & 60 & 66,7 & 72,2 \\
\hline 23. & $\begin{array}{c}\text { Students should build a clear } \\
\text { vision of their learning } \\
\text { English. }\end{array}$ & 65 & 75 & 44,4 & 61,1 \\
\hline
\end{tabular}


Table 8, items 19-23. The data of the experimental group demonstrated significant growth in students' understanding responsibility for finding their ways of practising English in as Item $19(30 \% \rightarrow 95 \%)$, while control groups' data grew more moderate: $27,8 \% \rightarrow 38$, $9 \%$. The same situation can be observed in item 20 , demonstrating students' realizing the necessity to use self-study materials (experimental: $15 \% \rightarrow 55 \%$, control: $16,7 \rightarrow 33,3 \%$ ). Item 21 is demonstrating students' awareness to evaluate themselves to analyze the strengths and weaknesses to learn better. The data of the experimental group $(20 \% \rightarrow 70 \%)$ and control group $(11,1 \% \rightarrow 11,1 \%)$ is evidence of a favourable environment for students' autonomy fostering. Item 22 demonstrated students' believing whether they mostly have to study information mentioned under the course for exam purpose: the experimental remained unchanged $60 \%$, control grew $66,7 \% \rightarrow 72,2 \%$ ). Item 23 showed the respondents' ideas on the importance to build a clear vision of their learning before learning English. The data of the experimental group demonstrated confidence and full support $(65 \% \rightarrow 75 \%)$, which proves students' autonomy development. While the control group's data grew more moderate $(44,4 \% \rightarrow 61,1 \%)$.

Table 9. Learners' perceptions of teachers' role.

\begin{tabular}{|c|c|c|c|c|c|}
\hline \multirow{2}{*}{ No } & Items & \multicolumn{2}{|c|}{$\begin{array}{c}\text { experimental } \\
\text { group (\%) }\end{array}$} & \multicolumn{2}{|c|}{$\begin{array}{c}\text { control } \\
\text { group (\%) }\end{array}$} \\
\cline { 3 - 6 } & Sept & May & Sept & May \\
\hline 24. & $\begin{array}{c}\text { A lot of learning can be done } \\
\text { without a teacher. }\end{array}$ & 40 & 50 & 27,8 & 33,3 \\
\hline 25. & $\begin{array}{c}\text { Teachers have to be } \\
\text { responsible for making } \\
\text { students understand English. }\end{array}$ & 70 & 55 & 83,3 & 88,9 \\
\hline 26. & $\begin{array}{c}\text { Teachers should point out the } \\
\text { students' errors. }\end{array}$ & 85 & 45 & 83,3 & 77,8 \\
\hline 27. & $\begin{array}{c}\text { Teachers not only have to } \\
\text { teach 'what' but should also } \\
\text { teach 'how' of English. }\end{array}$ & 55 & 40 & 61,1 & 61,1 \\
\hline 28. & $\begin{array}{c}\text { Teachers have to provide } \\
\text { exam-oriented notes and } \\
\text { materials. }\end{array}$ & 100 & 60 & 100,0 & 77.8 \\
\hline 29. & $\begin{array}{c}\text { The failure of the students is } \\
\text { directly related to the } \\
\text { teachers' employment }\end{array}$ & 65 & 30 & 77,8 & 61,1 \\
\hline
\end{tabular}

Table 9, items 24-29. The data of experimental and control groups demonstrated respondents believing that a lot of learning can be done for themselves as is shown in item 24 (experimental $40 \% \rightarrow 50 \%$ (which proves some students' autonomy development), while the control group remained the same $27,8 \% \rightarrow 27,8 \%$ ). The data of Item 25 demonstrated students' difference in perception of the idea about teachers' responsibility for making students understand English (experimental: $70 \% \rightarrow 55 \%$, control: $83,3 \% \rightarrow 88,9 \%$ ). This result is evidence of students' autonomy development in the experimental group because it proves some changes in students' understanding of teachers' role as a partner or a facilitator, but not a person only responsible for the result of students' progress. Item 26 showed developments in students' ideas about error correction by a teacher (experimental: $85 \% \rightarrow 45 \%$, more than half of a total number of respondents were able to understand the need to correct the mistakes for their own; control $83,3 \% \rightarrow 77,8 \%$. Item 27 demonstrated the changes in respondents' understanding of what and how teachers have to teach. The data of the experimental group is $55 \%$ $\rightarrow 40 \%$, which means that students decide for themselves how they should learn information, and the data of the control group remained unchanged: $61,1 \% \rightarrow$ $61,1 \%$. Item 28 showed students' attitudes to teachers' provision exam-oriented notes and materials (experimental group: $100 \% \rightarrow 60 \%$ and control group $100 \% \rightarrow 94,4 \%$ ). Item 29 demonstrated the connection between the students' failure with the teachers' classroom employment. The data of the experimental group showed significant changes in students' understanding: $65 \% \rightarrow 30 \%$, and the control group $77,8 \% \rightarrow 61,1 \%)$.

The changes in students' autonomy level at the beginning and the end of the experiment demonstrate some changes between experimental and control groups $(\mathrm{E} \rightarrow \mathrm{E}$ vs $\mathrm{C} \rightarrow \mathrm{C})$ :

1. To diagnose students' awareness in language learning which includes students' perceiving of own abilities, possibilities and capabilities. Items:

- $1(40 \% \rightarrow 70$ vs $44,4 \% \rightarrow 38,9 \%)$;

- $6(10 \% \rightarrow 60 \%$ vs $5,6 \% \rightarrow 27,8 \%)$;

- $14(0 \% \rightarrow 85 \%$ vs $11,1 \rightarrow 33,3)$.

The experimental group demonstrated significant changes in comparison with the control group.

2. To find out students' level of willingness to development and their ability to set personal learning goals. Items:.

- $2(15 \% \rightarrow 65 \%$ vs $27,8 \% \rightarrow 33,3 \%)$;

- $335 \% \rightarrow 75 \%$ vs $22,2 \% \rightarrow 33,3 \%)$;

- $4(0 \% \rightarrow 35 \%$ vs $5,6 \rightarrow 16.7 \%)$;

- $5(25 \% \rightarrow 70 \%$ vs $22,2 \% \rightarrow 22,2 \%)$;

- $8(0 \% \rightarrow 35 \%$ vs $0 \% \rightarrow 11,1 \%)$;

- $14(0 \% \rightarrow 85 \%$ vs $11,1 \% \rightarrow 33,3 \%)$;

- $17(35 \% \rightarrow 85 \%$ vs $16.7 \% \rightarrow 50.0 \%)$;

- $21(20 \% \rightarrow 70 \%$ vs $11,1 \rightarrow 11,1 \%)$;

$-23(65 \% \rightarrow 75 \%$ vs $44,4 \% \rightarrow 61.1 \%)$.

The experimental group demonstrated considerable positive changes in comparison with the control group.

3. To discover students' readiness to accept responsibility for learning, assess and reflect on own progress. Items:

- $9(0 \% \rightarrow 45 \%$ vs $0 \% \rightarrow 22,2 \%)$;

- $13(0 \% \rightarrow 30 \%$ vs $0 \% \rightarrow 27,8 *)$;

- $14(0 \% \rightarrow 85 \%$ vs $11,1 \% \rightarrow 33,3)$.

Positive changes in the experimental group compared to the control group are more noticeable.

4. To identify students' learning strategies and their readiness to develop study plans to achieve these goals. Items:

- $7(5 \% \rightarrow 30 \%$ vs $5,6 \% \rightarrow 16,7 \%)$;

- $9(0 \% \rightarrow 45 \%$ vs $0 \% \rightarrow 22,2 \%)$;

- $11(35 \% \rightarrow 75 \%$ vs $33,3 \% \rightarrow 61,1 \%)$.

The experimental group demonstrated positive changes in comparison with the control group.

5. To come to know about students' ability to select relevant resources and support. Items:

- $9(0 \% \rightarrow 45 \%$ vs $0 \% \rightarrow 22,2 \%)$; 
- $10(0 \% \rightarrow 0 \%$ vs $0 \% \rightarrow 0 \%$--students don't use the traditional libraries);

- $11(35 \% \rightarrow 75 \%$ vs $33,3 \% \rightarrow 61,1 \%)$;

- $12(15 \% \rightarrow 55 \%$ vs $22,2,3 \% \rightarrow 22,2 \%)$;

- $13(0 \% \rightarrow 30 \%$ vs $0 \% \rightarrow 27,8 \%)$

$-15(50 \% \rightarrow 90 \%$ vs $66,7 \rightarrow 66.7 \%)$;

- $16(45 \% \rightarrow 75 \%$ vs $50,0 \% \rightarrow 55,6 \%)$;

- $18(60 \% \rightarrow 95 \%$ vs $55,6 \rightarrow 100 \%)$.

The experimental group demonstrated considerable positive changes in comparison with the control group. 6. To distinguish students' attitude to the role of the teacher. Items:
- $19(30 \% \rightarrow 95 \%$ vs $27,8 \% \rightarrow 38,9 \%)$;

- $24(40 \% \rightarrow 50 \%$ vs $27,8 \% \rightarrow 33,3 \%)$;

- $27(55 \% \rightarrow 70 \%$ vs $61,1 \% \rightarrow 61,1 \%)$.

Positive changes in the experimental group compared to the control group are more noticeable.

7. Items which do not demonstrate the students' autonomy development are:

- $22(60 \% \rightarrow 60 \%$ vs $66.7 \% \rightarrow 72,2 \%)$;

- $25(70 \% \rightarrow 55 \%$ vs $83,3 \% \rightarrow 88,9 \%)$;

- $26(85 \% \rightarrow 45$ vs $83,3 \rightarrow 77,8)$;

- $28(100 \% \rightarrow 60 \%$ vs $100 \% \rightarrow 77,8 \%)$;

- $29(65 \% \rightarrow 30 \%$ vs $77,8 \% \rightarrow 61,1 \%)$.

Table 10. Results of students' language competency testing before and after the experiment.

\begin{tabular}{|c|c|c|c|c|c|c|c|c|c|c|}
\hline \multirow{3}{*}{ Marks } & \multicolumn{5}{|c|}{ Experimental group } & \multicolumn{5}{|c|}{ Control group } \\
\hline & \multicolumn{2}{|c|}{ Before the experiment } & \multicolumn{2}{|c|}{ After the experiment } & \multirow{2}{*}{\begin{tabular}{|c|} 
Differences \\
$\%$
\end{tabular}} & \multicolumn{2}{|c|}{ Before the experiment } & \multicolumn{2}{|c|}{ After the experiment } & \multirow{2}{*}{\begin{tabular}{|c|} 
Differences \\
$\%$
\end{tabular}} \\
\hline & Students & $\%$ & Students & $\%$ & & Students & $\%$ & Students & $\%$ & \\
\hline $\mathrm{A}$ & 6 & 30 & 11 & 55 & +25 & 6 & 33,3 & 8 & 44,4 & $+11,1$ \\
\hline B & 7 & 35 & 4 & 20 & -15 & 7 & 38,8 & 6 & 33,3 & $-5,5$ \\
\hline $\mathrm{C}$ & 7 & 35 & 5 & 25 & -10 & 5 & 27,7 & 4 & 22,2 & $-5,5$ \\
\hline Total & 20 & 100 & 20 & 100 & & 18 & 100 & 18 & 100 & \\
\hline
\end{tabular}

Table 10. The results of the testing students' in the control and experimental groups at the beginning of the academic year demonstrated nearly the same level of competence in experimental and control groups. The results of the tests were received using the ECTS grading scale (A - 100-90; B - 89-82; C - 81- 75; D - 74-67; E 66-60). According to the results of tests conducted at the beginning of the year, $30 \%$ of students of the experimental group had A-marks. After the experiment, the percentage of students with A-marks increased to $55 \%$. The difference reached $+25 \%$. The percentage of students with B marks was $35 \%$ before and $20 \%$ after the experiment, the decrease constituting $-15 \%$. Similarly, the percentage of students in the experimental group with $\mathrm{C}$ marks decreased from $35 \%$ to $25 \%$ with a difference of $-10 \%$. In the control group, the differences in the level of learning progress before and after the experiment were not so significant. Level A after the experiment had $44,4 \%$ (vs.33,3\% before the experiment), B level before the experiment had 38,8 \% and after $33,3 \%$. There was also a less significant (in comparison with the experimental group - 5,5\% vs. $-10 \%$ ) decrease in the number of the students with $\mathrm{C}$ level after the experiment. The results of the testing are summarized in Table 10

\section{Conclusion}

Learner autonomy is a deeply-rooted phenomenon in the educational systems of Western countries, whereas in Ukrainian educational traditions it is rather new and unnatural. In our country, although official educational policies, which encourage the implementation of learner autonomy, many teachers at secondary schools and university levels tend to use methods they are familiar with. The special approach to ESP learning used in the experimental group was rather unusual and uncomfortable at the beginning for the students as well as their teacher. But soon all the participants began to fulfil the conditions of the experiment. The main task of the teacher was to teach the students how to learn the language, which means, from our point of view, to outline own plans of mastering content, to gain experience in applying structures, to analyze own mistakes made in the text and many actions more. But through the experimental work students realized their capabilities. The results of the questionnaire prove the fact of the special learning environment in the experimental group was created (at least its initial stage). This environment is characterized by favourable conditions for students' autonomy fostering. They are neutral attitude to mistakes and positive for their analysis; a comprehensive friendship with students creativity in learning; gentleness in planning changes, but a clear requirement to capture all aspects of learning content.

According to the results of the experiment, we can state that only a part of the most active students used the created conditions and gained experience in autonomous learning. They participated in a selection of study materials, willingly maintained diaries (blogs) in which analyzed own work and the work of peers. They were able to find opportunities to practice particular English vocabulary in and out of the classroom, tried to set own goals and honestly evaluated the work. As a result of continuous work, they became able to identify own strengths and determine own pace in learning. Being persistent they attended lessons regularly and worked hard acquiring necessary skills during the year of the project work. In addition to the above, we can mention that these students are intrinsically motivated and have a high level of academic performance. No wonder such students have succeeded. Their number in the experimental group is $11+4=15(55 \%(\mathrm{~A})$ and $20 \%(\mathrm{~B}))$, which makes up $65 \%$.

The limited teaching hours at the non-linguistic university, which devoted to ESP, were not enough to change completely the learning habits and styles of all the students and make them active autonomous learners. 
Some students from the experimental group (35\%) were not a success. We see the main problem in their general unpreparedness to change, absence skills of information acquiring, inability to choose the most important among the minor, unwillingness to take responsibility for own training. We consider it appropriate to note that many students from the control group became interested in the work of the project and expressed a desire to participate in the work of the next project, but in the experimental group.

As an important way to promote the development of autonomy, we consider:

1) the favourable atmosphere in the classroom, mutual assistance, and scaffolding provision;

2) the maintenance of students' blogs or educational diaries.

We can conclude that during the work of our experiment we used the special approach which involved:

- active teaching methods (such as doing projects and presentations based on students' creativity);

- developing students' independent work at different stages of the experiment (e.g. educational, training, and searching tasks united by common requirements (the clarity and controllability of results and accounting in the appraisal));

- paying due attention to the use of students' feedback and self-reflection (students were asked to keep written journals or blogs to help them to identify their strength and weaknesses of learning);

- maintaining a high level of motivation (learning topics were strictly related to problems of the future speciality); - stimulating the development of critical thinking (using tasks for analyzing, synthesizing, and, evaluating information, providing different perspectives upon the same material).

In such circumstances, the teacher was informed about students' likes and dislikes in the learning process, and was acting as a consultant.

As a result of the experimental work, new skills have been formed among the students of the experimental group, which include abilities to determine the learning objectives, to select methods and techniques of content assimilation, to monitor the procedure of learning, and to find reference materials as well as evaluate the results. That is what we mean under the notion of student's autonomy.

This approach was useful for the development of writing skills and the ability to express feelings and attitudes to the studied material. Such work enabled students to analyze their studies and see further prospects. This type of work significantly expanded students' professional horizons, made them feel involved in the process of learning. We believe it can be applied to all learning activities.

We also understand that our research is based on the student questionnaires result, which can be called rather subjective. At the same time, the indicators of students learning success are becoming evidence of the usefulness of the ESP approach mentioned above. The approach made a positive influence on students' motivational intensity, they became more satisfied with learning English and their results in education became better. This allows us to state that our experience contains a rational grain, is useful and deserves further development.

Creating an environment fostering learners' autonomy at non-linguistic university is a challenge that is appropriate to realize to give an autonomous learning experience to aspiring students. In our opinion, the development of students' autonomy is an indispensable condition of study at a modern university. Such an environment for learning is an important factor in students' learning activities intensification.

As we see the problem future researches should be dedicated to a need for learners' autonomy levels determination, because of lack of certainty in this realm. Another problem worthy to be investigated is the dependence of students' personal qualities and their autonomy development.

Besides, we consider the necessity to start the formation of students' autonomy in learning foreign languages at a young age as soon as possible. Because this process has many psychological factors worthy, to begin with at school and foster at the university level.

\section{References}

1. D. Little, Learner autonomy and second/foreign language learning, in The Guide to Good Practice for Learning and Teaching in Languages, Linguistics and Area Studies (CIEL Language Support network, 2003), https://www.researchgate.net/publication/25987462 4_Learner_autonomy_and_second_foreign_languag e_learning. Accessed 01 Dec 2019

2. V. Karastateva, M. Krasteva, Fostering Autonomy in ESP. Proceedings of the University of Ruse 49(6.3) (2010)

3. $\mathrm{Ph}$. Benson, Teaching and researching autonomy in language learning (Longman, London, 2001)

4. Ph. Benson, Autonomy in language teaching and learning. Language teaching 40, 21-40 (2006). doi:10.1017/S0261444806003958

5. H. Holec, Autonomy and Foreign Language Learning (Pergamon, Oxford, 1981)

6. D. Little, Learning as dialogue: The dependence of learner autonomy on teacher autonomy. System 23(2), 175-181 (1995). doi:10.1016/0346251X(95)00006-6

7. A. Finch, Autonomy: Where are we? Where are we going?

https://www.academia.edu/6022949/Autonomy_Wh ere_are_we_Where_are_we_going. Accessed 12 Dec 2019

8. Ph. Benson, P. Voller, Autonomy and Independence in language learning (Longman, London, 1997)

9. D. Thanasoulas, Learner Autonomy in ELT. Newsletter 32.9(2) (2000)

10. W. Littlewood, Defining and developing autonomy in East Asian contexts. J. App. Ling 20, 71-94 (1999). doi:10.1093/applin/20.1.71 
11. L. Bajrami, Teacher's new role in language learning and in promoting learner autonomy. Procedia-Social and Behavioral Sciences 199, 423-427 (2015). doi:10.1016/j.sbspro.2015.07.528

12. G. Gamble, M. Wilkins, Learner autonomy dimensions: What motivated and unmotivated EFL students think. Lingua Posnaniensis (2018). doi:10.2478/linpo-2018-0003

13. L.Dickinson, Self-Instruction in Language Learning (Cambridge University Press, Cambridge, 1987)

14. W. Littlewood, "Autonomy": anatomy and a framework. System 24, 427-435 (1996)

15. L. Dickinson, Learner Autonomy 2: Learner Training for Language learning (Authentik, Dublin, 1992)

16. N. Okumus-Ceylan, Thoughts on learner autonomy in a computer-assisted language learning program. IOJET 6(2), 339-354 (2019)

17. K. Joshi, Learner perceptions and Teacher Beliefs about Learner Autonomy in Language learning. NELTA 16(1-2), 13-29 (2011). doi:10.3126/nelta.v16i1-2.6126 